\title{
Achievements, experiences and challenges of the battle against poverty in China's ethnic minority areas: focusing on the "three areas and three prefectures"
}

\author{
Yanzhong Wang ${ }^{1} \cdot$ Sai Ding ${ }^{1}[$
}

Received: 18 November 2021 / Accepted: 19 November 2021 / Published online: 31 December 2021 (c) The Author(s) 2021

\begin{abstract}
The incidence of poverty in three of China's provinces (Qinghai, Guizhou and Yunnan) and five of its autonomous regions (Inner Mongolia, Guangxi, Tibet, Ningxia, and Xinjiang) is greater than the national average. As severely impoverished areas in China and top priorities in the country's battle against poverty, ethnic minority areas, especially the most impoverished "three areas" (the Tibet Autonomous Region, prefectures and counties with large Tibetan populations in the provinces of Qinghai, Sichuan, Gansu and Yunnan, and the Hotan, Aksu, Kashgar prefectures and Kizilsu Kirgiz Autonomous Prefecture in southern Xinjiang) and the "three prefectures" (the Liangshan Yi Autonomous Prefecture in Sichuan Province, the Nujiang Lisu Autonomous Prefecture in Yunnan Province, and the Linxia Hui Autonomous Prefecture in Gansu Province) showed a significant reduction in poverty and achieved decisive progress in poverty elimination from 2018 to 2019. This laid a solid foundation for the building of a moderately prosperous society in an all respects by 2020 . By reviewing and explaining methods and measures of targeted poverty alleviation used in ethnic minority areas of China, this paper summarizes the most successful experiences of these areas, particularly the "Three Areas and Three Prefectures", in the process of alleviating poverty and building a moderately prosperous society in all respects. These successful experiences consist of four aspects: roles of national systems, promotion of key poverty alleviation efforts, improved mechanisms and systems for targeted poverty alleviation, and specific innovative methods and measures. While examining the difficulties of eliminating poverty and building a moderately prosperous society in all respects in China's ethnic minority areas, especially in the
\end{abstract}

Sai Ding

dingsai@cass.org.cn

Yanzhong Wang

wangyanzhong01@163.com

1 Institute of Ethnology and Anthropology, Chinese Academy of Social Sciences, Beijing, China 
"Three Areas and Three Prefectures", this article also discusses practical challenges and problems yet to be solved, such as follow-up adjustments of poverty alleviation policies, cultivation of self-development capacity and weak educational foundations. Ultimately, this paper offers relevant solutions and suggestions in relation to macro policies, government officials and impoverished groups.

Keywords Battle against poverty - Building a moderately prosperous society in all respects $\cdot$ Targeted poverty alleviation $\cdot$ Ethnic minority areas $\cdot$ China

\section{Abbreviation}

CPC The Communist Party of China

\section{Introduction}

On February 25, 2021, at a grand gathering held to mark China's achievements in poverty alleviation and honor its model fighters of poverty, Chinese President Xi solemnly declared that victory in the battle against poverty had been achieved, and that China had completed the arduous task of eliminating extreme poverty: "Through the combined efforts of the whole Party and the entire nation, China has secured a complete victory in its fight against poverty in this important year with the centennial of the Communist Party of China (CPC) fast approaching. All of the 98.99 million rural residents, 832 counties, and 128,000 villages that fell below the current poverty line have now been lifted out of poverty. Regional poverty has been eliminated on the whole, and the arduous task of eradicating absolute poverty has been completed, representing yet another miraculous achievement!"

From the founding of the People's Republic of China in 1949 to the 7th FiveYear Plan period (1985-1990), rather than carrying out large-scale special poverty alleviation work, China relied heavily on economic development in poverty alleviation. Before 1986, the Chinese government's primary strategy of eradicating poverty was providing assistance to impoverished groups in rural areas via civil affairs departments and collective economic organizations to guarantee their survival. In May 1986, the General Office of the State Council of the People's Republic of China (State Council) issued the Notice on the Establishment of the State Council Leading Group for Economic Development in Poverty-stricken Areas, establishing the State Council Leading Group for Economic Development in Poverty-stricken Areas (renamed the State Council Leading Group for Poverty Alleviation and Development in 1993). After this, local governments in China created leading institutions for poverty alleviation and development at all levels to lead, organize, coordinate, supervise and inspect poverty alleviation and development. During the 7 th Five-Year Plan period, the basic policy of development-driven poverty alleviation was established: the policy would be shifted from relief-based poverty alleviation to development-driven poverty alleviation in order to support the development of impoverished areas. In 1986, 18 areas were designated by the Chinese Central Government as poverty-stricken, and 331 counties were identified as poverty-stricken 
at the national level. Furthermore, the governments of provinces and autonomous regions in the country singled out 368 provincial-level poverty-stricken counties. The national poverty line was set at RMB 200 (the per capita income of farmers in 1984). Moreover, poverty alleviation funds were set aside for increased financial investment in poverty-stricken areas. Based on the 1984 poverty line, the population lacking adequate food and clothing in rural China dropped from 125 million in 1985 to 75 million in 1993, with an average annual decrease of 6.25 million.

In 1994, the State Council launched the Priority Poverty Alleviation Program (1994-2000). This program was committed to ensuring that the basic needs of the remaining 80 million impoverished rural residents would be met within the seven years from 1994 to 2000. In 1994, during the implementation of the Program, the criteria for selecting poverty-stricken counties were redefined, and 592 povertystricken counties in China were identified according to the new criteria. In addition, investment in poverty alleviation was significantly increased, poverty alleviation through science and technology was strengthened, non-governmental forces were mobilized to participate in poverty alleviation, and more emphasis was placed on direct support for impoverished families. The key achievements were as follows: the economy in poverty-stricken areas achieved rapid growth; the gap between the average income of farmers in poverty-stricken areas and that of farmers in other areas of China was narrowed; infrastructure in poverty-stricken areas was significantly improved; and public services covering education, healthcare and culture were greatly enhanced. By 2000, the number of rural residents without adequate food and clothing in China dropped to 32.09 million as per the poverty standard at the time.

In 2001, the CPC Central Committee and the State Council issued the Outline for Development-driven Poverty Alleviation in Rural Areas (2001-2010), resulting in a new phase of rural poverty alleviation and development. The strategic objectives set in the Outline were to: 1 ) meet the basic needs of a very small number of impoverished people as soon as possible; 2) further improve the basic production and living conditions in poverty-stricken areas and consolidate the results of satisfying basic needs of impoverished people; 3 ) bolster the quality of life and overall quality of impoverished people, strengthen construction of infrastructure in poverty-stricken villages, improve the ecological environment, and gradually change the social, economic and cultural backwardness of poverty-stricken areas, so as to create suitable conditions for realization of a moderately prosperous life. With regard to policies and measures, in 2001, the Chinese Central Government renamed "national-level poverty-stricken counties" as "key counties of national poverty alleviation and development work", and removed the quotas of 33 poverty-stricken counties in six eastern provinces and the quota of poverty-stricken counties in Tibet, reallocating them to other central and western provinces and regions. As a contiguous impoverished area, Tibet was granted comprehensive support, and the Chinese Central Government was no longer responsible for poverty alleviation in the six eastern provinces. In 2008, the Chinese government raised the poverty line from an annual per capita net income of RMB 895 to RMB 1196. The number of people targeted for poverty alleviation grew by 30 million. A rural poverty alleviation scheme featuring the government as leader, social participation, and encouragement of self-reliance was also formed. In addition, a national rural minimum living security system was 
established. Ten years of development-driven poverty alleviation achieved extraordinary results: According to the poverty line in 2008, the number of impoverished people in rural areas plummeted from 94.22 million to 26.88 million, and the basic needs for the vast majority of the impoverished people have been met.

In 2011, the Chinese government issued the Outline for Development-driven Poverty Alleviation in Rural Areas (2011-2020), putting forward new poverty alleviation objectives and strategies. As per the Outline, the strategic goals of poverty alleviation in China's rural areas from 2011 to 2020 were as follows: impoverished people in rural areas would be guaranteed adequate food and clothing, access to compulsory education, basic medical services, and safe housing by 2020; the per capita net income of farmers in poverty-stricken areas would grow at a rate higher than the national average; the indicators of the major areas of basic public services would be close to the national average; and the trend of widening development gaps would be reversed. Furthermore, for the first time, the Outline clearly proposed that poverty alleviation carried out via industries, special poverty alleviation programs and social assistance would form the three basic methods of poverty alleviation in China's rural areas in order to create a large-scale poverty alleviation network (Yang 2017). In 2011, the Chinese government raised the poverty line established in 2010 from RMB 1274 to RMB 2300, an increase of 80.5\%. This increase caused the number of rural impoverished residents able to benefit from poverty alleviation policies to rise by 100 million. Starting in 2014 , China's rural poverty alleviation and development shifted to a model of comprehensive, targeted poverty alleviation which was implemented throughout the entire process of identifying the impoverished, arranging targeted programs, utilizing capital, taking assistance measures, contacting officials in charge of poverty elimination, and conducting reviews of poverty alleviation.

In 2015, the Decision of the CPC Central Committee and the State Council on Winning the Battle Against Extreme Poverty was promulgated and implemented. In 2018, the Guidelines of the CPC Central Committee and the State Council on the Three-Year Action Plan to Win the Battle Against Extreme Poverty were released. In 2019, the State Council Leading Group for Poverty Alleviation and Development issued the Guiding Opinions on Solving the Outstanding Problems in the "Two Assurances and Three Guarantees." The introduction of the above-mentioned policies demonstrates that the CPC Central Committee highly valued the fight against poverty and was determined to lift all people out of poverty. All CPC members, from top leaders to grassroots officials, worked together to resolve real difficulties. Since the 18th National Congress of the CPC, the impoverished population of China has been reduced by 82.39 million, with more than 12 million people being lifted out of poverty each year (Zheng et al. 2012). The 2020 Government Work Report pointed out that, in 2019, decisive achievements were made in poverty alleviationthe rural poor population was reduced by 11.09 million, and the incidence of poverty fell to $0.6 \%$ ( $\mathrm{Li} 2020$ ).

From 2018 to 2019, all regions of China, especially ethnic minority areas and the severely impoverished "three areas and three prefectures," innovated poverty alleviation models through various methods such as developing tourism and industries, carrying out ecological protection and building the CPC, thus boosting the sustainable development capacity of poverty-stricken areas and embarking upon a path of 
poverty alleviation with Chinese characteristics, consisting of "people-centered philosophy," "highlighting poverty alleviation in the governance of China," "eradicating poverty through development," "pressing ahead with poverty alleviation based on reality," "letting the poor play the principal role," and "pooling all resources to create synergy." 1

Following the development of targeted poverty alleviation and the battle against poverty in China, many Chinese scholars have analysed and studied the paths, achievements, experience and challenges of poverty alleviation through industries, social assistance and special poverty alleviation programs in ethnic minority areas from the perspectives of ethnology, anthropology, economics and sociology. They have also analysed and studied the results of poverty alleviation and satisfaction with it, characteristics of impoverished groups, the influence of natural environmental conditions on poverty and the contribution of improved public services to poverty alleviation, among other aspects. Their research methods include both macro-level strategic analysis and theoretical analysis of poverty alleviation and micro-level poverty alleviation research on impoverished families and individuals based on different survey data.

At home and abroad, ethnic studies have yielded fruitful results in practical follow-ups and theoretical research on poverty alleviation and development as well as targeted poverty alleviation.

In the pre-reform era of the People's Republic of China, many rural people lived in poverty. Since the beginning of economic reform at the end of the 1970s, remarkable progress in poverty reduction has taken place in rural China. However, this progress has been uneven with regard to time and place (Chen and Ravallion 2010; Khan 2008; Ravallion and Chen 2007; World Bank Group (世界银行集团) 2019). Poverty alleviation features on China's political agenda and ambitions in this country, which is experiencing rapid economic growth, are high (Gustafsson et al. 2021). Noticing China's alteration of its poverty alleviation methods, some foreign scholars have analyzed and studied changes in the characteristics of those in poverty affected by these changes using micro survey data (Gustafsson and Zhong 2009). Dibao, or the Minimum Livelihood Guarantee, is China's last-resort safety net for social assistance, as well as the world's largest public assistance program. As China's largest social assistance program in terms of its number of beneficiaries, Dibao has played a vital role in China's alleviation of poverty over the past 20 years (Qin 2017; Zhang 2017).

Based on a large amount of data, this paper summarizes the concrete achievements, experiences and challenges of the battle against poverty in ethnic minority areas from 2018 to 2019. China showed strong timeliness and practical significance in meeting all poverty eradication targets and building a moderately prosperous society in all respects in 2020. This paper also sums up the successful experiences of the battle against poverty in ethnic minority areas and explains them from the perspective of economic theories. Furthermore, while analysing the difficulties of

\footnotetext{
${ }^{1}$ Full Text: China's Epic Journey from Poverty to Prosperity - Xinhua http://www.xinhuanet.com/ english/2021-09/28/c_1310214205.htm
} 
eliminating poverty and building a moderately prosperous society in all respects in ethnic minority areas, especially in the "three areas and three prefectures", this paper also discusses urgent challenges and problems, such as follow-up adjustment of poverty alleviation policies, cultivation of self-development ability and weak educational foundations.

\section{Research methods}

This paper applies the method of literature research. From the perspective of ethnic economy, this paper, based on research and statistical data collected in recent years and China's national policies, displays a complete picture of the battle against poverty in China's ethnic minority areas in three respects: the specific paths of poverty alleviation in three of China's provinces and five of its autonomous regions, especially in the "three areas and three prefectures" from 2018 to 2019, and the achievements and the experiences of these, in a bid to facilitate deeper understanding of China's poverty alleviation strategies.

\section{Results: achievements of the Battle against poverty in ethnic minority areas (2018-2019)}

Since the start of the battle against poverty, significant progress has been made in China's ethnic minority areas. In 2018, the incidence of poverty in China's ethnic minority areas fell to $4 \%$. Although this was higher than the national incidence of poverty of $1.7 \%$, this statistic had decreased by 2.9 percentage points since 2017 , and the number of people living in poverty had declined by 4.3 million. In 2019 , the battle against poverty in ethnic minority areas entered its final stage, with the incidence of poverty in these areas only $0.19 \%$ higher than the national average (Table 1).

\section{Achievements of the Battle against poverty in the "Three Areas and Three Prefectures" $^{2}$}

The number of impoverished people in the "three areas and three prefectures" decreased from 1.72 million in 2018 to 430,000 by the end of 2019 , and the incidence of poverty dropped from $8.2 \%$ to $2 \%$ (Cao et al. 2020).

In 2018, absolute poverty in Xinjiang, not including the four prefectures in southern Xinjiang, was essentially eliminated. In that year, a total of 486,900

\footnotetext{
${ }^{2}$ The "three areas" in the "three areas and three prefectures" refer to the Tibet Autonomous Region, the four prefectures in southern Xinjiang and the Tibetan ethnic areas in the provinces of Sichuan, Yunnan, Gansu, and Qinghai; the "three prefectures" refer to the Linxia Hui Autonomous Prefecture in Gansu Province, the Liangshan Yi Autonomous Prefecture in Sichuan Province and the Nujiang Lisu Autonomous Prefecture in Yunnan Province
} 
Table 1 Comparisons between the poverty-stricken population and incidence of poverty in the three provinces and five autonomous regions with large ethnic minority populations (hereinafter referred to as "the three provinces and five autonomous regions") and the poverty-stricken population and incidence of poverty in all of China

\begin{tabular}{|c|c|c|c|c|}
\hline & \multicolumn{2}{|c|}{ Poverty-stricken population (unit: 10,000 ) } & \multicolumn{2}{|l|}{ Incidence of poverty $(\%)$} \\
\hline & $\begin{array}{l}\text { In the three provinces and five } \\
\text { autonomous regions }\end{array}$ & In China & $\begin{array}{l}\text { In the three provinces and five } \\
\text { autonomous regions }\end{array}$ & In China \\
\hline 2013 & 2562 & 8249 & 17.1 & 8.5 \\
\hline 2014 & 2205 & 7017 & 14.7 & 7.2 \\
\hline 2015 & 1813 & 5575 & 12.1 & 5.7 \\
\hline 2016 & 1411 & 4335 & 9.4 & 4.5 \\
\hline 2017 & 1032 & 3046 & 6.9 & 3.1 \\
\hline 2018 & 603 & 1660 & 4.0 & 1.7 \\
\hline 2019 & 119 & 1109 & 0.79 & 0.6 \\
\hline
\end{tabular}

Note: The 2013-2016 data in the table are extracted from Poverty Alleviation Progress Report in Minority Areas of China, Neac.gov.cn and Stats.gov.cn (The 2013-2016 data in the table are extracted from Poverty Alleviation Progress Report in Minority Areas of China (2018) (中国少数民族地区扶贫进展 报告(2018)) written by Zhang Lijun, Wu Benjian, Wang Fei, Ma Bo, et al. (张丽君, 吴本健, 王飞, 马博 等), Economic Press China (中国经济出版社), 2019, pp. 4-5, and Monitoring of Rural Poverty in Ethnic Minority Areas in 2017 (2017年民族地区农村贫困监测情况) published on Neac.gov.cn (国家民委网 站) on 17 August 2018. The 2018 data are from the Great Progress in Poverty Relief and Development \& Historic Achievements in Poverty Alleviation-The 15th Part of the Series Reports on the Achievements of Economic and Social Development in the 70th Anniversary of the Founding of the People's Republic of China (扶贫开发持续强力推进 脱贫攻坚取得历史性重大成就一一新中国成立70周年经济社会 发展成就系列报告之十五) by Household Office, National Bureau of Statistics (国家统计局住户办) on Stats.gov.cn (国家统计局网) on 12 August 2019. The 2019 data are from Director of the State Ethnic Affairs Commission: The poverty rate in the eight ethnic minority provinces and autonomous regions has dropped from 4\% to $0.79 \%$ (国家民委主任:民族八省区贫困人口发生率已从 $4 \%$ 下降到 $0.79 \%$ ) written by Guo Jingyuan (郭静原), published on Ce.cn of Economic Daily (经济日报-中国经济网) on 11 January 2020; as well as reports on the work of the government over the years.)

people in 513 poverty-stricken villages lifted themselves out of poverty. The incidence of poverty decreased from $18.3 \%$ at the end of 2017 to $10.51 \%$ at the end of 2018. In 2019, Xinjiang saw decisive progress in the battle against poverty: 645,000 people were lifted out of poverty, poverty was wiped out in 976 povertystricken villages and two counties designated as poverty-stricken, and the incidence of poverty was reduced to $1.2 \%$ (Wang 2020).

As of 2018, Tibet had helped 55 poverty-stricken counties (districts) to eradicate poverty, "lifted 4,714 poverty-stricken villages (residences) out of poverty, helped 478,000 people shake off poverty, and lowered the incidence of poverty from 35.2\% as it had been before 2015 to below 6\%" (Chang 2019). In 2019, poverty was eliminated in all 19 remaining poverty-stricken counties (districts). As a result, Tibet took the lead in completing comprehensive poverty alleviation in the severely impoverished "three areas and three prefectures."

The Linxia Hui Autonomous Prefecture in Gansu Province invested RMB 2.6 billion in poverty alleviation in 2018 , a year on year increase of $108 \%$. In the 
same year, 112,200 people were lifted out of poverty, poverty was wiped out in 160 villages, and the incidence of poverty was diminished to $8.97 \%$ (Ma 2020).

As of 2018, the Liangshan Yi Autonomous Prefecture in Sichuan Province had helped 199,000 people shake off poverty, helped 500 villages eliminate poverty, and reduced the incidence of poverty to $7.1 \%$. At the end of 2019 , the prefecture set the target of helping 238,000 people and 445 poverty-stricken villages shake off poverty. In the same year, 141,000 people were lifted out of poverty and poverty was wiped out in 318 villages (Suga 2019).

In 2018, poverty was eliminated in 19 poverty-stricken villages, 30,200 impoverished people were lifted out of poverty in the Nujiang Lisu Autonomous Prefecture in Yunnan Province, and the entire population of Dulong shook off poverty. By the end of 2019, the overall goals of the Two Assurances and Three Guarantees for impoverished people in the Prefecture had been realized, 90,000 people had been lifted out of poverty, poverty had been eradicated in 146 villages, Gongshan County had been lifted out of poverty, and the entire population of Pumi had shaken off poverty (Li 2019).

\section{Achievements of the Battle against poverty in ethnic minority areas}

Ethnic minority areas have fully implemented the three-year action plan in order to win the battle against extreme poverty. They have spared no effort in tackling severe issues discovered during special inspections on poverty alleviation carried out by central government inspection teams and reviews of poverty alleviation work, vigorously advancing the battle against poverty and achieving remarkable outcomes.

In 2018, the Inner Mongolia Autonomous Region promoted targeted poverty alleviation, lifting 235,000 people out of poverty, and helping 10 national povertystricken counties and 13 regional poverty-stricken counties to eliminate poverty $(\mathrm{Bu}$ 2019). In 2019, poverty was erased in all 20 remaining poverty-stricken counties in Inner Mongolia and all 676 remaining poverty-stricken villages in Gacha. Throughout the whole year, 141,000 people were lifted out of poverty, the number of impoverished people was reduced to 16,000 , and the incidence of poverty plunged from $11.7 \%$ to $0.11 \%$ (Han 2020a, 2020b).

In the Guangxi Zhuang Autonomous Region, the population living in poverty was reduced by 8.25 million between 2012 and 2018, with an average annual reduction of 1.17 million, and the incidence of poverty decreased from $18 \%$ to $3.7 \%$. In 2019 , over 1.25 million impoverished people were lifted out of poverty, poverty was wiped out in 1268 villages and 21 counties, and the incidence of rural poverty in the entire region dropped below 1\% (Chen 2019).

50 severely poverty-stricken villages in the Ningxia Hui Autonomous Region cast off poverty in 2018. 25,000 impoverished people were relocated from inhospitable areas to places with better economic prospects, 115,000 people shook off poverty, and the incidence of poverty diminished to $3 \%$ (Xian 2019). In 2019, the incidence of poverty in Ningxia fell to $0.47 \%$. Poverty was eliminated in four of its counties (prefectures) and 109 of its villages, and 103,000 impoverished people were lifted out of poverty (Li and Shi 2020). 
The population of Guizhou Province living in poverty decreased by 1.48 million in 2018. The incidence of poverty dropped to $4.3 \%$, poverty was eliminated in 14 counties, and 761,900 impoverished people were relocated from inhospitable areas to places with better economic prospects (Shen 2019). In 2019, Guizhou planned to reduce the number of impoverished people in rural areas by more than 1.1 million and relocate 1.88 million impoverished people from inhospitable areas to places with better economic prospects ${ }^{3}$.

In Yunnan Province, the population living in poverty decreased by 1.51 million in 2018 , and the incidence of poverty plunged from $14.03 \%$ in 2015 to $5.39 \%{ }^{4}$. In 2019, Yunnan focused on severely impoverished areas and devoted efforts to dealing with the acute problems of the Two Assurances and Three Guarantees. Yunnan was dedicated to ensuring that 1.3 million people were lifted out of poverty, that poverty was erased in 2457 villages, that 31 counties would cast off poverty, and that poverty for all members of the seven "directly-entering-socialism ethnic groups" was eliminated (Ruan 2019).

Poverty was eliminated in 526 villages and 176,000 people were lifted out of poverty in Qinghai Province in 2018. The incidence of poverty decreased from $8.1 \%$ in 2017 to $2.5 \%$, and poverty was wiped out in 12 counties (Wang and Yang 2019). In 2019, poverty was eradicated in the 170 remaining poverty-stricken villages, 77,000 people were lifted out of poverty, and 17 counties shook off poverty. Both regional and overall poverty were hereby brought to an end in Qinghai (Wang 2015).

\section{Discussion: practical experiences from the Battle against poverty in ethnic minority areas}

At the critical point of the battle against poverty, ethnic minority areas, especially the "three areas and three prefectures," created a large-scale poverty alleviation network combining policies, special programs, industries, finances, assistance, party-building and infrastructure. In these ethnic minority areas, poverty alleviation projects were carried out and multiple aspects of poverty alleviation work conducted were closely related to impoverished families and individuals, and covered industry, employment, ecology, education, health and social security. Notably, new measures were taken in these areas, and solid progress was made in consolidating the achievements of poverty alleviation. This effectively reduced the risk of slipping back into poverty and prevented potential new poverty risks. Follow-ups after relocating the impoverished were implemented, and

\footnotetext{
${ }^{3}$ CPC Guizhou Provincial Party Committee and the Guizhou Provincial People's Government (中共 贵州省委贵州省人民政府), “Action Order of the CPC Guizhou Provincial Party Committee and the Guizhou Provincial People's Government for the Decisive Battle against Poverty in 2019 Summer and Autumn” (中共贵州省委贵州省人民政府2019年脱贫攻坚夏秋决战行动令), [N]. Guizhou Daily (贵 州日报), 13 July 2019 (5).

4 Yunnan Reporter Station of China Daily (中国日报网云南记者站), “Yunnan Has Scored a Decisive Victory In Poverty Alleviation” (云南省脱贫攻坚取得了决定性胜利), Chinadaily.com.cn (中国日报 网), 31 January 2019.
} 
the the self-drive and self-development abilities of impoverished areas and people were enhanced.

The main experiences of ethnic minority areas in stimulating poverty alleviation and securing decisive victory in building a moderately prosperous society in all respects were as follows:

1. Using top leadership in these areas to attach great importance to promoting poverty alleviation by specifying clear objectives, allocating responsibilities to subordinate departments at different levels, and giving full play to institutional advantages and the efficiency of concentrating forces on major tasks

The top-level design of China's poverty governance formed the overall layout for poverty alleviation. A report at the 19th CPC National Congress indicated that the energy of the entire Party, country and society should be mobilized, and targeted poverty reduction and alleviation measures should continue to be implemented. They were to operate based on a working mechanism whereby the central government would make overall plans, provincial-level governments would take overall responsibility, and city and county governments would ensure implementation, strengthening this responsibility system in which the chief leaders of the party and government would take overall responsibility (The Party History and Literature Research Office of the CPC Central Committee 2018). These principles were highlighted in the battle against poverty in ethnic minority areas and the "three areas and three prefectures".

In Tibet, a headquarters for poverty alleviation was established, headed by a Member of the CPC Standing Committee of Tibet and the Executive Vice Chairman of Tibet. The headquarters was composed of capable personnel from relevant departments, and 11 special teams were established, responsible for areas such as policy and support, planning and design, relocation of impoverished people and employment. Related headquarters were also set up in cities, counties and townships throughout the region. In this way, a working mechanism was established whereby top leaders at all levels took charge of poverty alleviation, department leaders dealt with specific poverty alleviation matters and relevant departments worked in coordination, thus forming greater synergy to solve the problems of poverty alleviation (which involved a wide range of complicated tasks), and to ensure the smooth progress of all poverty alleviation work.

The CPC and government officials have played an important role in the battle against poverty in the four prefectures in southern Xinjiang. In 2018, the People's Government of the Xinjiang Uygur Autonomous Region dispatched more than 70,000 officials to southern Xinjiang to help impoverished residents in over 10,000 villages shake off poverty. In the same year, the Government selected 1289 first CPC secretaries for 1289 severely poverty-stricken villages in the four prefectures in southern Xinjiang, including 31 department-level officials, 869 division-level officials, and 389 young division-level reserve officials and other 
excellent officials. Institutions of higher learning in Tibet also selected 1289 staff members, 546 of whom had bilingual ability. ${ }^{5}$

In 2018, the People's Government of Sichuan Province introduced 34 policies and measures concerning 12 areas of Liangshan Yi Autonomous Prefecture on top of the 10 existing customized poverty alleviation programs, and set aside RMB 3.708 billion of funds for poverty alleviation at all levels. The Government released the Implementation Plan for the Selection and Management of Comprehensive Assistance Teams for Poverty Alleviation in the Liangshan Yi Autonomous Prefecture, and selected more than 5700 officials to form comprehensive assistance teams to visit 11 severely poverty-stricken counties in the prefecture in order to implement a three-year poverty alleviation and comprehensive assistance program. ${ }^{6}$

The leading provincial and regional level officials in Qinghai, Yunnan, Guangxi, Ningxia, and Inner Mongolia were deeply involved in poverty alleviation, planning, promoting, and supervising poverty alleviation. The "five-level CPC secretaries" comprehensively fulfilled their responsibilities in poverty alleviation and continued to promote poverty alleviation work.

In 2019, the governments of ethnic minority areas turned addressing the problems stated in the national review of poverty alleviation work into a major political task, proactively identifying gaps and adopting special measures to handle these issues. These governments continued to take responsibility for alleviating poverty, with a view to comprehensively improving the quality and efficiency of poverty alleviation work.

Traditional development economics, academic theories and perspectives, such as the trickle-down theory, credit economic growth with poverty reduction (Chenery et al. 1974; World Bank 2000; Dollar and Kraay 2002), the "immiserizing growth" that emerged alongside economic growth in some countries in the 1960s (Whitfield 2008), and the "pro-poor growth" that has evolved since then (Ravallion 2001), suggest that while the experience of many countries has proved the positive role of economic growth in poverty reduction, the scale of this role is dependent on structural features and supporting security measures in place during the course of economic growth (Li and Wei 2016a, 2016b). Studies have shown that the reduction of poverty in China began to slow down significantly after the mid-1980s (Zhao et al. 1999). This means that China's reduction of poverty was gradually compromised by its economic growth. After China had experienced rapid economic growth for a long time, the problems of uneven regional development, the increasing urbanrural income gap, and large base population living in poverty not only limited the reach of benefits from economic development, but may also negatively affect future economic development potential. The experience of many countries has demonstrated that bridging the economic development gap is not an easy task, and this situation is complicated further by non-economic factors. Therefore, it is meritorious,

\footnotetext{
5 Poverty Alleviation and Development Office of Xinjiang Uygur Autonomous Region (新疆维吾尔自 治区扶贫开发办公室), 2018 Poverty Alleviation News Report No. 52 (2018年扶贫简报第52期).

6 Sichuan Daily, 2018. “Determination to Eradicate Deep Poverty in Liangshan” (坚决啃下凉山深度贫 困这块硬骨头). 2018. [N]. Sichuan Daily (四川日报), 21 June 2018 (6).
} 
internationally unsurpassed and incredible to explore the advantages of concentrated efforts and institutional efficiency in fighting against poverty and build a moderately prosperous society in all respects.

2. Focusing on the effectiveness and efficiency of poverty alleviation with increased financial investment and partner assistance to overcome all difficulties and challenges along the way

In 2018, the Central Government allocated RMB 106.095 billion worth of special funds to poverty alleviation, and the Ministry of Finance pledged all additional funds of RMB 20 billion to support poverty alleviation in severely impoverished areas. RMB 12 billion of this was used to support the "three areas and three prefectures" in their fight against poverty. Of the special funds for poverty alleviation, RMB 48.619 billion was allocated to the three provinces and five autonomous regions which accounted for $45.83 \%$ of the country, and RMB 6.686 billion went to Tibet, which made up $13.75 \%$ of the "the three provinces and five autonomous regions" (Zhang and Yu 2018). In 2019, the special funds allocated to poverty alleviation by the Central Government were increased to RMB 126.095 billion, and the additional RMB 20 billion was mainly used in the "three areas and three prefectures" and other poverty-stricken areas. The available funds rate for "three areas and three prefectures" exceeded the $95 \%$ of the three-year plan, and the project completion rate was over $85 \%$ (2018). The special funds for poverty alleviation in "the eight provinces and autonomous regions" accounted for $47.2 \%$ of the country, $1.37 \%$ higher than in 2018 .

In Inner Mongolia, livelihood expenditure accounted for $70.1 \%$ of the region's general public budget expenditure in 2018, and financial investment for poverty alleviation at all levels amounted to RMB 14.79 billion, an increase of $21.6 \%$. In 2019, each level of government in Inner Mongolia successively invested RMB 9.923 billion in special funds for poverty alleviation, and the central government allocated RMB 2.458 billion to this purpose, a year-on-year increase of $5 \%$. Meanwhile, the autonomous region's government invested RMB 4.487 billion, a year-on-year increase of 7\%. Throughout the year, 107 enterprises were introduced to help 34,500 impoverished people find employment inside and outside of the region. Moreover, the central authorities directly invested RMB 208 million into poverty alleviation, attracted supporting funds amounting to RMB 566 million, and introduced 214 projects, enabling 87,000 impoverished people to increase their income (Han 2020a, 2020b).

Devoting $80.5 \%$ of its financial expenditure to peoples' livelihood, Guangxi made improving people's lives its top priority in 2018. To promote targeted measures for poverty alleviation, various types of funds were introduced, such as financial investment, government bonds and microcredit for poverty alleviation, totaling nearly RMB 70 billion. In 2019, Guangxi received RMB 8.4 billion worth of funds allocated by the central government for poverty alleviation, and the autonomous region's financial expenditure on peoples' livelihood increased by $9.6 \%$ compared with in 2018 . 
Guizhou allocated over RMB 17 billion of budgetary funds to poverty alleviation in 2018, 3.4\% of which accounted for general public budget expenditure ${ }^{7}$ and RMB 6 billion of which went to severely impoverished areas. For 16 poverty-stricken counties, the provincial government allocated more special funds of RMB 100 million in both 2018 and 2019. Meanwhile, solid efforts were made to promote collaboration on poverty alleviation and targeted poverty alleviation between the eastern and western regions, and cooperation on poverty-alleviation with the Macao Special Administrative Region. A campaign calling on state-owned and private enterprises to assist villages was also held. With the introduction of the Poverty Alleviation Cloud platform and the Poverty Alleviation Hotline, the village revitalization strategy was launched, attracting RMB 80.2 billion of investment in the creation of a beautiful countryside.

Yunnan Province spent more than $70 \%$ of its financial expenditure on peoples' livelihood in 2018. With central funding of RMB 779 million $^{8}$, it strived to invest in and establish 18 poverty alleviation projects in the field of healthcare services within the central budget. Supporting measures in education, health care, and housing were promoted, and the funding standard for low-income households in rural areas was raised to no less than RMB 3500 per person per year. Collaboration between Shanghai and Yunnan, and Guangdong and Yunnan on poverty alleviation was also further promoted.

Since the implementation of the poverty alleviation strategy in Tibet in 2016, the central government has continued to increase its support for impoverished areas, with special funds allocated to poverty alleviation reaching RMB 126.1 billion in 2019, an annual increase of over RMB 20 billion for four consecutive years ${ }^{9}$ (State Council Leading Group for Poverty Alleviation and Development 2019). In 2018, Tibet coordinated and integrated various types of financial funds amounting to RMB 16.73 billion related to agriculture at all levels, and a total of RMB 14.49 billion was invested in the relocation of 218,000 impoverished people (Qi 2019). According to rough statistics gained from interviews with farmers and herdsmen, over two-thirds of the actual income of Tibetan farmers and herdsmen comes from government transfer income, which constitutes a relatively high percentage of income for impoverished farmers and herdsmen.

Qinghai Province invested various special funds totalling RMB 11.44 billion in poverty alleviation in 2018, a year-on-year increase of $8.6 \%$. Of this sum, RMB 3.428 billion was allocated by the central government, and RMB 1.452 billion came from the provincial government, up 35.2\% and 38.3\%, respectively (Wang 2019).

\footnotetext{
7 Calculated based on China Statistical Yearbook (2019) and Report on the Work of Guizhou Provincial Government (2019).

8 Yunnan Provincial Health and Family Planning Commission: Public Notice on the Arrangement of Health Poverty Alleviation Funds published on 24 July 2018.

9 State Council Leading Group Office of Poverty Alleviation and Development (国务院扶贫开发领 导小组), "Ministry of Finance: The Central Government Will Allocate 126.1 Billion Yuan for Poverty Alleviation This Year” (财政部:今年安排中央专项扶贫资金1261亿), [N]. People's Daily (人民日报), 17 July 2019 (6).
} 
In the same year, Jiangsu Province allocated annual funds of RMB 275 million to Qinghai, as part of partner assistance (Wang 2020).

Under the increased pressure of increased financial revenue, Ningxia spent $76 \%$ of its financial resources on securing and improving peoples' livelihood in 2018. Continuous efforts have been made to enhance collaboration between Fujian and Ningxia on poverty alleviation, and with combined policies on industry, employment, finance, education and healthcare poverty alleviation, a total of RMB 10.92 billion was invested in fighting poverty. In addition, coverage of microcredit for poverty alleviation reached $85 \%$.

Xinjiang received RMB 10.403 billion from 19 provinces and cities for the purpose of poverty alleviation in 2018. 1484 officials were assigned temporary positions and 2535 professional and technical talents were dispatched. 1716 social organizations provided assistance to 3438 impoverished villages, investing RMB 226 million. 1157 private enterprises invested a total of RMB 1.287 billion to help 237,800 people in poverty, and the China Glory Society launched a campaign to invest RMB 2.76 million in public welfare. In addition, the military assisted in the construction of 14 Bayi Aimin Schools, and invested RMB 69.78 million in construction to help 9 county hospitals in impoverished counties. 16 central authorities offered pairing assistance to 27 poverty-stricken counties, investing RMB 183 million and implementing 131 projects (Poverty Alleviation Office in Xinjiang Uygur Autonomous Region 2019). In 2019, Xinjiang allocated RMB 37.567 billion of financial funds to poverty alleviation ${ }^{10}$. Moreover, 19 provinces and cities designated to provide paired assistance to Xinjiang continued to focus on poverty alleviation and peoples' livelihood, with investment of RMB 18.819 billion and implementation of 1935 projects, greatly supporting Xinjiang's efforts regarding poverty alleviation, livelihood improvement and economic development (Guan 2020).

Many studies have shown that countries or regions with high rates of investment bridge the development gap faster (Easternlin 1981; Abramovitz 1979, 1985). Economics and public choice theory argue that there is a fundamental difference between resource allocation efficiency and redistribution. That is, the allocation of resources needed for economic growth can guide society from points inside the Pareto front to a point upon it through market allocation. In contrast,

\footnotetext{
10 The "three transformations" reform refers to the transformation from resources to assets, the transformation from funds to shares and the transformation from farmers to shareholders. The transformation from resources to assets refers to making efficient use of the natural resources such as collective land, forest land and water area by means of equity participation for the village collective; The transformation from funds to shares refers to, without changing the nature and purpose of the use of funds, quantifying the funds from governments of all levels, including the rural agricultural production development funds (excluding subsidies, relief, emergency funds), agricultural resources and ecological protection subsidy funds (excluding the cash given directly to farmers), poverty alleviation and development funds, rural infrastructure construction funds, village collective development supporting funds, as equity shares of the village collective and then investing them to all kinds of business entities, allowing the village collective and farmers (poor households are prioritized) to participate in profit sharing; The transformation from farmers to shareholders refers to the fact that farmers become shareholders of business entities by investing their individual resources, assets, funds, technologies, skills etc., and participate in profit sharing.
} 
public choice theory generally believes in the Pareto optimum of the redistribution process, provided that the collective choice process is less anarchic than the market. In other words, the problems of allocating the benefits of collective action through the political process are more prominent than the problems of allocating benefits of private goods through market exchange (Mueller 2011). China's fight against poverty consists not only of high state-led investment in underdeveloped regions, but also an extended redistributive process from an economic perspective. In the short term, rapid economic growth in impoverished regions has been driven by intensive large-scale investments, particularly in infrastructure, as demonstrated by the strong economic growth in the three provinces and five autonomous regions from 2013 to present. In the long run, this is intended to lay the foundation for future national economic development, using a redistributive approach to rapidly improve allocative efficiency. General Secretary Xi has stated that poverty alleviation is not merely about building a moderately prosperous society in all respects, but is also a necessary and inevitable requirement for China to focus on solving the problem of unbalanced and insufficient development, vigorously improve the effectiveness and efficiency of development, more effectively meet the growing economic, political, cultural, social, and ecological needs of the people, and further promote comprehensive development of all people and social progress .

3. Innovating the approach to eliminate poverty based on local conditions, with alignment of economic and social development with the goal of poverty alleviation, and focus on improving long-term mechanisms to fight poverty

Based on specific conditions in different regions, all levels of governments in ethnic minority areas study the alignment, opportunities, and difficulties and challenges arising from poverty alleviation during rural revitalization and coordinated regional development, and are constantly innovating ways to alleviate poverty. One example of this is the industry-led solution with policy support and medical insurance to prevent impoverished people from falling into or slipping back into poverty due to illness. By supporting small and medium-sized enterprises in the "three areas and three prefectures" and impoverished ethnic minority areas, the central enterprises designated to provide pairing assistance have cultivated entrepreneurial leaders. As industrial investment funds in impoverished areas have been set up with the help of central enterprises, and investment and development companies have been established, central enterprises have assisted in the development of advantageous industries in the areas, thus improving the self-development capacity of impoverished areas. With further poverty alleviation efforts aimed at the development of industry, ecology and infrastructure, the collective economy of rural professional cooperatives has grown, and the process of specialization and modernization of agriculture and animal husbandry has been accelerated. Focusing on the goal of industry-driven poverty alleviation, rural cultural tourism has gradually become a pillar industry. In order to ensure the effectiveness of poverty alleviation and prevent impoverished people from slipping back 
into poverty, some ethnic minority areas have begun to conceive feasible ways in which to effectively strengthen policy support for groups with income levels slightly higher than those of documented impoverished households. Meanwhile, a targeted poverty prevention mechanism based on policy support and medical insurance has been especially established for barely out-of-poverty households and low-income households prone to falling into poverty.

Tibet has issued more than 60 regulatory documents on poverty alleviation and has fundamentally established a well-supported policy system covering different areas such as financial investment, financial support, land policy, poverty alleviation through industry development and ecological compensation. With poverty alleviation efforts directed towards industrial development, poverty alleviation strategies in areas such as relocation and education have been proactively implemented. The Tibet Office of the China Banking Regulatory Commission has introduced 19 financial policies and measures under 6 categories for poverty alleviation, forming a financial policy system with poverty alleviation efforts geared towards loan services for relocation, industrial development, and households in need that has achieved outstanding results.

Xinjiang has incorporated poverty alleviation into the framework of general requirements for work in the region to jointly promote efforts in anti-terrorism and stability maintenance, construction of the core area of the Silk Road Economic Belt, rural revitalization and tourism development. In particular, the implementation of land administration and redistribution has been a major innovation in improving income distribution and promoting social equity in the four southern Xinjiang regions' fight against poverty. The key method is to reclaim the irregularly administered wasteland according to law. In accordance with the management methods of state-owned and collective land, the Poverty Alleviation Office leads the relevant departments of agriculture, forestry, animal husbandry and land to distribute recovered cultivated land between impoverished households, following the principles of territorial, quantified and need-based allocation, so as to effectively increase the substantial income of impoverished households.

In the Three-Year Action Plan for Poverty Alleviation Through Tourism in the Inner Mongolia Autonomous Region (2018-2020), it is stated that Inner Mongolia plans to launch 200 demonstration projects for poverty alleviation through tourism within three years to promote tourism-focused poverty alleviation efforts (Liu and Zhang 2018).

Guizhou has taken the lead in implementing the incentive measure of continuing to follow poverty alleviation policies even after removal from the poverty list, exploring implementation of "three transformations" reform ${ }^{[5]}$, setting up the first investment fund of RMB 300 billion for poverty alleviation, innovating the "Tangyue Experience" in poverty alleviation led by the CPC, and innovating and improving the poverty alleviation mechanism for relocation, the financing method for rural infrastructure construction, and employment training for impoverished labor forces in rural areas (Liu 2018).

Qinghai Province has developed five leading industries for poverty alleviation with local characteristics, covering yak, barley, photovoltaic technology in villages, rural tourism and ethnic handicrafts, and realized $100 \%$ coverage in collective 
economic support funds. Qinghai's targeted poverty alleviation efforts have led to the establishment of a large-scale poverty alleviation network through constant improvement of organization and leadership systems, accurate identification, supervision and discipline, and assessment and evaluation, along with implementation of the village support mechanism, targeted help and pairing assistance, and mechanisms for special poverty alleviation, corporate and social assistance, and collaboration and pairing assistance between the eastern and western regions.

With the implementation of specialty industry upgrading in poor areas, and the introduction of industrial projects, technical training, microcredit, assistance measures and agricultural insurance for impoverished households, as well as the development of Chinese herbal medicine, minor grain crops, rural e-commerce and rural tourism, Ningxia has established a new pattern of poverty alleviation in which every village is home to an industry in order to eliminate poverty, and in which every household has options for increasing their income.

In its fight against poverty, Yunnan has endeavored to become China's most beautiful province, making an all-out effort to create a pleasant environment with clear air, clean water, and green lands. In addition, it has constructed facilities for centralized treatment of sewage from industrial parks at the provincial level and above, and has delineated forbidden and restricted areas for the breeding of livestock within the province.

Guangxi has achieved $100 \%$ coverage of poverty alleviation through industrial development for poor households with development capabilities, and has promoted innovative models, such as selling cattle to households on credit and buying them back at market price once they are ready for slaughter, livestock breeding with different parties working in coordination, and encouraging workshops to employ local workers. Meanwhile, the development of specialty industries has been largely driven by increasing the number and scale of leading enterprises, standardizing and promoting farmers' cooperatives, and cultivating entrepreneurial leaders in impoverished villages. Guangxi has also developed a unified and dynamically managed big data platform for the purpose of poverty alleviation, and established the business management mechanism of utilizing data in analysis, decision-making, management, and innovation. ${ }^{11}$

Economic development and growth are mainly derived from production factors such as land, capital, labor, and technology. In particular, technological development is a key driver of economic growth and a necessary concomitant leading to the growth of new physical investment and human capital investment (Nelson 2001). Today's innovation system is inseparable from the strong competition driven by continuously evolving technology, and the support of a well-developed education and training system, as well as high investment in enterprises and equipment. The economy of ethnic minority areas, especially in impoverished ethnic regions and the "three areas and three prefectures", is lagging behind the rest of the country, and the economic development gap with the developed eastern regions, especially in

\footnotetext{
11 "Guangxi Has Built a Big Data Platform For Poverty Alleviation" published by Poverty Alleviation and Development Office of Guangxi Zhuang Autonomous Region.
} 
terms of technological progress, cannot be narrowed in the short term. Most innovative poverty alleviation models focus on rapid improvement of the factors of capital, technology and labor, and intensive external intervention to effectively promote transformation of the industrial structures in poor ethnic regions and the "three areas and three prefectures" in the short term, and accelerate agricultural modernization and the development of agricultural industries using local strength. In addition, the increase in human capital as a result of accelerated urbanization and improved medical and social security not only lays the foundation and establishes potential for future economic development in impoverished ethnic minority areas and "three areas and three prefectures", but in the long term and on a national scale, also renders inclusive and shared development more sustainable and effective as the development gap between regions is gradually narrowed and a wider range of regions and populations begin to engage in market competition.

4. Urging grassroots officials to engage in poverty alleviation, and encouraging the CPC, government departments, the military, enterprises and public institutions at all levels to provide targeted and pairing assistance to poor regions, with all parties working in coordination to fight poverty

At the National Conference on Development-driven Poverty Alleviation, General Secretary Xi Jinping stated that the focus on encouraging grassroots officials to promote poverty alleviation was an important experience for poverty-stricken areas in eliminating poverty and becoming more well off. In ethnic minority areas, especially the "three areas and three prefectures", grassroots officials have made joint efforts in poverty alleviation through industrial development, relocation, employment, education and healthcare. Under the leadership of the CPC and with the support of the grassroots officials, the poverty alleviation campaign takes the party's political and organizational advantages and leverages its close relations with the people to establish a poverty alleviation network whereby all parties work together to fight poverty (Yang 2018). This has been demonstrated in ethnic minority areas, especially in the "three areas and three prefectures", where an innovative approach has been developed to continuously extend the coverage of party organizations and tasks mainly by setting up party organizations in poverty-stricken areas, based on industrial chains, cooperatives, collective economic organizations, and production groups (Qian 2018). All state-level departments and institutions, people's organizations, institutions managed in accordance with civil service law, key large state-owned enterprises, state-controlled financial institutions, key national scientific research institutes, and military and armed police forces have carried out targeted assistance to alleviate poverty. They have focused on integrating various types of poverty alleviation resources into their efforts in relocation, education, healthcare, and infrastructure construction in impoverished counties. In addition, government officials have been dispatched to villages to work at the front line of poverty alleviation. In this way, poverty alleviation-related policies, decision-making, and measures stipulated by the Party Central Committee, the State Council, the provincial party committee, and the provincial government can be effectively communicated and implemented, 
making it possible to achieve remarkable results in terms of industrial development, project management, supervision of poverty alleviation funds, and cultivation of grassroots officials. Intensive efforts on poverty alleviation through targeted measures, dispatch of officials, pairing assistance, education, and consumption have not only boosted the confidence of impoverished areas and poor households in eliminating poverty, but their skills and overall capabilities have also been improved with various types of training. Moreover, with the accumulation of and increase in human capital, the ability of the people to lift themselves out of poverty and their future adaptability to social development have been strengthened.

\section{Conclusion: challenges and solutions for ethnic minority areas in securing decisive victory in building a moderately prosperous Society in all Respects}

2019 and 2020 were critical in the battle against poverty and the building of a moderately prosperous society in all respects. Although decisive progress has been made in the battle against poverty, and the goal of building a moderately prosperous society is on the verge of being achieved, there will be many remaining difficulties and challenges along the way, and the situation is still grim. The following challenges and difficulties must continue to be taken seriously.

1. The task of poverty alleviation in extremely impoverished areas is arduous. The work related to the prevention of slipping back into poverty must be further strengthened, and it is very difficult to determine durations of support policies for counties and populations that have recently shaken off poverty according to local conditions.

As some ethnic minority areas are extremely impoverished, poverty eradication work and the task of supportive poverty alleviation is more difficult in these areas. In addition, there are still gaps between the implementation of responsibilities, policies and work in the battle against poverty and the goals established. On the other hand, harsh natural environments, extremely fragile ecosystems, frequent natural disasters and unfavorable economic and social conditions in these deeply impoverished areas render the task of poverty eradication especially arduous. Currently, of the more than 93 million previously registered impoverished people who have been lifted out of poverty in China, nearly 2 million are at risk of slipping back into it. Meanwhile, nearly 3 million people on the verge of poverty are at risk of falling into it (Qi et al. 2019). 2020 marked the year of building a moderately prosperous society in all respects, and to complete the task of poverty alleviation, some regions emphasized and relied upon financial and material input-based assistance. Although concentrating resources on impoverished households and villages can quickly lift them out of poverty in the short term, once external support is withdrawn or weakened, they are bound to return to poverty in varying degrees. In addition, governments at all levels act as policy makers, investors, specific implementers and managers, and 
supervisors in the battle against poverty. The question of how to give full play to government functions in poverty alleviation while stimulating the vitality of market mechanisms and genuinely involving social organizations will have a direct bearing on the normalization of poverty alleviation after the establishment of the moderately prosperous society.

In addition, industrial foundations of ethnic minority areas remain weak and generally unsustainable, and it is difficult to determine how long the established policies should be maintained and how they should be phased out in order to consolidate the results of poverty elimination.

2. The proportion of industries that leverage local strengths to alleviate poverty must be increased. Some industries lack the impetus for subsequent development, and some poor areas have not yet developed the ability to develop themselves.

General Secretary Xi Jinping pointed out that "Poverty alleviation through development of local industries is the fundamental solution to ensure eradication of poverty. However, poverty alleviation work in most areas now favors shortterm and quick effects, failing to fully consider long-term benefits and stable growth of income, making it difficult to achieve long-term effects. The question of how to consolidate the effectiveness and sustainability of poverty elimination is an important issue that must be faced and addressed properly in order to fight the battle against poverty." Current problems in ethnic minority areas include the homogenization of industries in poverty alleviation projects, the slow process of localization of core sectors such as organizational management and technical departments, and the weakness of infrastructure, especially that which supports industrial development. Human resources, land and capital are clearly insufficient to meet the long-term sustainable development needs of industries.

Setbacks in economic globalization, shocks to the international financial market, and particularly China-US economic and trade frictions have all had adverse effects on the production and business operations of companies and on market expectations. We have faced severe challenges caused by the growing pains of economic transformation. An interlacing of old and new issues and a combination of cyclical and structural problems have brought changes to what used to be a generally stable economic performance, resulting in some cause for concern (Li 2019). The economic development of counties in ethnic minority areas still tends to be underdeveloped, and it will be difficult for these areas to achieve the goal of "industrial revitalization" on their own. At present, many poverty alleviation industries in ethnic minority areas rely on the support of central enterprises or eastern regions. Moreover, most of those who directly participate in distribution of income from the assistance projects are "jobless and unable to get out of poverty." Poverty alleviation industries mainly provide local low-end employment. Therefore, cultivation of self-development capacity in these areas still has a long way to go.

3. The situation of impoverished people lacking a sense of competition and intrinsic motivation for self-development is difficult to change in the short term. Education 
in impoverished areas is weak, and further efforts are needed to prevent intergenerational transmission of poverty.

Although all levels of governments in ethnic minority areas have carried out various forms of ideological education by combining poverty alleviation with intellectual support in recent years, due to the influence of low education and the backward environment, some impoverished people are indifferent to market competition and maintain the attitude of "waiting for, relying on and requesting" aid. There are also some impoverished people who are easily satisfied with the status quo after receiving government transfer income and fail to take advantage of their current favourable situations and opportunities to increase their income. Moreover, harmful customs such as consumption and etiquette based on a mentality of rivalry still exist in some deeply impoverished areas. As such ways of thinking are out of touch with the market economy and modern society, these deeply-rooted problems cannot be solved within a short space of time.

Without a significant increase in natural resources and self-development capacity, rapid population growth will increase employment pressure and render resources more scarce, which will affect future poverty management in ethnic minority areas. For example, the annual population growth rate in the Tibet Autonomous Region increased from 2.1 times to 5.5 times from 2011 to 2018 , which was very significant compared to the rest of the country ${ }^{12}$. If we further consider that the urbanization rate of Tibet was $30.89 \%$ in 2017, it is clear that the population of Tibet, especially in pastoral areas, is increasing. Meanwhile, the mechanical growth rate of Tibet's population was $8.95 \%{ }^{13}$ in 2018 , showing an obvious tendency to stay on the homeland. Other deeply impoverished ethnic minority regions have seen the same trend. Therefore, sufficient attention must be paid to preventing inter-generational transmission of poverty.

In addition, there is a lack of educational resources in impoverished areas, where the teaching quality is low and students are not adequately motivated to learn. Education plays a limited role in interrupting the transmission of inter-generational poverty. In terms of future poverty alleviation, the challenge of inter-generational poverty eradication is more daunting than the current challenge of poverty alleviation in contiguous impoverished areas. Following social and technological progress, the quality of the workforce required in society has become increasingly demanding, making it more difficult for people to lift themselves out of poverty.

In 2018-2019, ethnic regions made every effort to eliminate deep poverty and secure decisive victory in building a moderately prosperous society in all respects. However, poverty alleviation is a long-term and continuous task, which should not only focus on building a moderately prosperous society by 2020 , but also plan for the subsequent implementation of the rural revitalization strategy, as well as the long-term stable and coordinated development of regional economy and society. Furthermore, the following measures and suggestions should be adopted:

12 Calculated based on the data from China Statistical Yearbook over the years.

13 Calculated based on the data from Tibet Statistical Yearbook (2019). 
Firstly, at the macro policy level, it is necessary to speed up the effective alignment of policies on poverty elimination for the building of a moderately prosperous society and rural revitalization. These policies should not only ensure that poverty elimination goals are achieved, but also prevent relapses into poverty to avoid continuation of existing policies, and comprehensively promote implementation of the rural revitalization strategy.

China's achievements in poverty alleviation and the building of a moderately prosperous society are remarkable. However, the situation regarding weak foundations and backward development of agriculture and rural areas has remained fundamentally unchanged. The most obvious shortcomings in economic and social development and the weakest link in modernization remain agriculture and rural areas. The economic development of ethnic minority areas, especially the process of agricultural modernization, is relatively underdeveloped in China. Therefore, it has become the main battlefield of poverty elimination in recent years. The core of local government management at all levels is the fight against poverty, using government functions covering policy formulation, capital investment, project planning, operation management, supervision and inspection. From the perspective of cost efficiency, this approach ensures strong execution and high efficiency, enabling the goals of poverty alleviation and the building of a moderately prosperous society to be successfully achieved. After the elimination of extreme poverty, overcoming relative poverty will remain a long-term and arduous task for China. In the future, emphasis should also be placed on further leveraging resource allocation functions and mobilizing social organizations to participate in poverty alleviation efforts. Policy formulation, and in particular, implementation, should be tailored to local conditions and adopt step-by-step approaches. Efforts must be made to consolidate the results of poverty alleviation while preventing new poverty risks, and to determine the pace of policy shifts and the timing and intensity of implementation in accordance with the general requirements and goals of the rural revitalization strategy.

In addition, collaboration between the eastern and western regions, corporate funding and social assistance have already resulted in achievements in poverty alleviation. These approaches should be continued after the realization of a well-off society in 2020 . However, the one-way grant aid should be gradually transformed to pairing assistance in line with the operation of market economy rules.

Secondly, the training of government cadres at all levels of politics, economics and law must be strengthened to concentrate on development with the goal of building a moderately prosperous society in all respects and rural revitalization. It should gradually shift from government-led poverty alleviation to market-led flexible resource allocation to constantly enhance the creativity and competitiveness of rural areas and agriculture, so as to achieve the goal of industrial development and prosperity. The government should lead the building of a moderately prosperous society in all respects and rural revitalization. The transformation of government functions requires government cadres at all levels to nurture awareness of market and competition, to obtain economic and legal expertise in industrial development, and to develop proper perception of government management. To this end, relevant training and ideological work for government cadres must be strengthened. 
Thirdly, education and training for individuals, especially impoverished individuals, should be strengthened to enhance their labor skills, and every effort should be made to prevent the inter-generational transmission of poverty.

The ethnic minority areas are characterised by poor overall education level, lacking skills of the labor force, and generally low level of human capital. These are the main difficulties in fighting poverty and building a moderately prosperous society in all respects. Increased attention should be paid to these areas during the post-2020 rural revitalization, and the coverage of education investment and labor skills training should be expanded. Basic education should focus on solving the problem of school-age children in ethnic minority areas dropping out due to boredom, stabilizing the teaching force, and improving transportation for children to and from school in remote and border mountain villages. Support for preschool education should also be strengthened. The assistance policy for pre-school education and education beyond high school should be extended to relatively poor families, and the subsidy standard for poor families at these two stages of education should be raised accordingly. Means and methods of vocational training should also be reformed to match the needs of society. Language training in standard spoken and written Chinese should be enhanced, the practical training method of "learning by doing" should be adopted and innovated, and vocational training for the transfer of rural laborers and agricultural technology training should be promoted in a coordinated manner.

Acknowledgements Not applicable.

Authors' contributions Yanzhong Wang: Overall research design;writing part of the original draft. Sai Ding (Corresponding author): Writing original draft. Revising. Both authors read and approved the final manuscript.

Funding Important progress of the fund project- "Research on Major Issues of Heightening a Sense of Identity of the Chinese Nation", one of the major innovation projects funded by the Chinese Academy of Social Sciences (Project Number: 2020ZDGH017).

Availability of data and materials All data generated or analyzed during this study are included in this published article

\section{Declarations}

Ethics approval and consent to participate Not applicable.

Consent for publication Not applicable.

Competing interests The authors declare no potential conflicts of interest.

Open Access This article is licensed under a Creative Commons Attribution 4.0 International License, which permits use, sharing, adaptation, distribution and reproduction in any medium or format, as long as you give appropriate credit to the original author(s) and the source, provide a link to the Creative Commons licence, and indicate if changes were made. The images or other third party material in this article are included in the article's Creative Commons licence, unless indicated otherwise in a credit line to the material. If material is not included in the article's Creative Commons licence and your intended use is not permitted by statutory regulation or exceeds the permitted use, you will need to obtain permission directly from the copyright holder. To view a copy of this licence, visit http://creativecommons.org/licen ses/by/4.0/. 


\section{References}

Abramovitz, Moses. 1979. Rapid growth potential and its realization: The experience of capitalist economics in the post-war period. In Economic growth and resources: The major issues, Vol.1, ed, ed. Edmond Malinvaud. London: Macmillan Press.

Abramovitz, Moses. 1985. Catching up, Forging Ahead, and Falling Behind. Journal of Economic History $46(2)$

Bu Xiaolin (布小林), “Report on the Work of the Inner Mongolia Autonomous Region Government 2019”(2019年内蒙古自治区政府工作报告), Nmg.gov.cn (内蒙古自治区政府网), 2019.

Cao Hongyan, Huang Junyi, Lu Min (曹红艳, 黄俊毅, 陆敏), “Pivotal Progress was Achieved in the Three Critical Battles against Poverty, Pollution, and Potential Risk” (三大攻坚战取得关键进 展), [N]. Economic Daily (经济日报), 2020 (2).

Chang Chuan (常川), “Tibet's Poverty Alleviation Efforts Have Been Praised by the State Council for Three Consecutive Years, And It Will Ensure Removing All Its Remaining 19 Impoverished Counties From the Poverty List This Year" (西藏脱贫成效连续3年获国办表扬今年将确保剩 余19个贫困县摘帽), China Tibet News Web (中国西藏新闻网), 2019.

Chen Wu (陈武), “Report on the Work of the Guangxi Government (Summary)” (广西政府工作报告 (摘要)), [J]. Guangxi Economy (广西经济), 2019 (1).

Chenery, H., M.S. Ahliwalia, C. Bell, J.H. Duloy, and R. Jolly. 1974. Redistribution with growth: Policies to improve income distribution in developing countries in the context of economic growth. Oxford: Oxford University Press.

Dollar, D., and A. Kraay. 2002. Growth is good for the poor. Journal of Economic Growth 3.

Easternlin, Richard A. 1981. Why Isn't the Whole World Developed? Journal of Economic History 47 (1): 2018

Guan Qiaoqiao (关俏俏), “Focus on Overcoming Deep Poverty-Four Prefectures in Southern Xinjiang are Making All-Out Efforts to Eradicate Poverty” (集中力量攻克深度贫困堡垒一一南疆四 地州脱贫攻坚正全力冲刺), Xinhuanet (新华网), 2020.

Gustafsson, Bjorn, and Wei Zhong. 2009. How and Why has Poverty in China Changed? A Study Based on Microdata for 1988 and 1995. The China Quarterly 164: 983-1006.

Gustafsson, Bjorn, Reza Hasmath, and Sai Ding. 2021. Ethnicity and poverty in China. Routledge Press.

Han Xueru (韩雪茹), “A Decisive Battle to Realize the Dream of a Well-off Society-A Review of Poverty Alleviation in Inner Mongolia in 2019” (决战决胜共圆小康之梦—2019年内蒙古脱 贫攻坚述评), [N]. Inner Mongolia Daily (内蒙古日报), 2020a (4).

Han Xueru (韩雪茹), “Decisive Progress in Poverty Alleviation Has Been Made in Inner Mongolia-The Autonomous Region Government Held a Press Conference to Brief about Its Poverty Alleviation Progress" [N], Inner Mongolia Daily (内蒙古日报), 2020b (3).

Li Keqiang (李克强), “Report on the Work of the Government 2019” (政府工作报告(2019)), Gov.cn (中国政府网), 2019.

Li Keqiang (李克强), “Report on the Work of the Government 2020” (政府工作报告(2020)), [N]. The Economic Observer (经济观察报), 2020 (3).

Li Peilin, Wei Houkai (李培林, 魏后凯主编), annual report on poverty reduction of China (中国扶贫 开发报告), Social Sciences Academic Press (社会科学文献出版社), 2016a, 13.

Li Peilin, Wei Houkai (李培林, 委鬼后凯主编), Annual Report on Poverty Reduction of China (2016) (中国扶贫开发报告(2016)), [M]. Social Sciences Academic Press (社会科学文献出版社), 2016 b.

Li Peishan, Shi Yujia (李佩珊, 石羽佳), “Four Impoverished Counties in Ningxia Are Expected to Be Removed From the Poverty List with Poverty Rate Dropping to 0.47\% “(宁夏脱贫攻坚4县区有 望摘帽 贫困发生率降至0.47\%), ECNS.CN (中国新闻网), 2020.

Li Wenhui (李文辉), “Report on the Work of the Nujiang Lisu Autonomous Prefecture Government 2019” (怒江傈僳族自治州政府工作报告(2019)), [N]. Nujiang Newspaper (怒江报), 2019 (3).

Liu Xiaoming (刘小明), “Guizhou: A Model Province For National Poverty Alleviation” (贵州:创全 国脱贫攻坚“省级样板”), [N]. Guizhou Daily (贵州日报), 2018 (5).

Liu Ze, Zhang Xuedong (刘泽, 张雪冬), “Inner Mongolia Has Made Solid Progress In Poverty Alleviation Through Tourism” (内蒙古扎实推进旅游扶贫), Inner Mongolia Channel of People.cn ( 人民网内蒙古频道), 2018. 
Ma Xueli (马学礼), “Report on the Work of the Linxia Prefecture Government (2018)” (临夏州政府 工作报告(2018年)), ThePaper.cn (澎湃新闻网), 2020.

Mueller, Dennis C., 2011. Public choice (公共选择理论), translated by Han Xu, Yang Chunxue et al. (韩旭, 杨春学), , [M]. China Social Sciences Press (中国社会科学出版社).

Nelson, Richard R., 2001. The sources of economic growth (经济增长的源泉), [M]. Economic press China (中国经济出版社), translated by Tang Guanghua et al. (汤光华等译).

Poverty Alleviation and Development Office of Xinjiang Uygur Autonomous Region (新疆维吾尔自 治区扶贫办), “Xinjiang's Achievements in Poverty Alleviation in 2018” (2018新疆亮出脱贫攻 坚成绩单), Xinjiang Channel of People.cn (人民网新疆频道), 2019.

Qi Zhala (齐扎拉), “Report on the Work of the Tibet Autonomous Region Government (2019)” (西藏 自治区政府工作报告(2019年)), [N]. Tibet Daily (西藏日报), 2019 (2).

Qian Zuyan (钱祖严), “Intensify Efforts To Strengthen Party Building And Promote Poverty Alleviation” (深入推进抓党建促脱贫攻坚), [N]. Guizhou Daily (贵州日报), 2018 (3).

Qin, Gao. 2017. Welfare, work, and poverty: Social assistance in China. Oxford University Press.

Ravallion, Martin. 2001. Growth, inequality and poverty: Looking beyond averages. World Development 29 (11).

Ruan Chengfa (阮成发), “Report on the Work of the Yunnan Provincial Government 2019” (2019年 云南省政府工作报告), Yn.gov.cn (云南省人民政府网), 2019.

Shen Yiqin (谌贻琴), “Report on the Work of the Guizhou Provincial Government 2019” (2019年贵 州省政府工作报告), [N]. Guizhou Daily (贵州日报), 2019 (2).

Suga Erbu (苏嘎尔布), “Report on the Work of the Liangshan Yi Autonomous Prefecture Government 2019” (2019年凉山彝族自治州政府工作报告), [N]. Liangshan Daily (凉山日报), 2019 (2).

The party history and literature research office of the CPC central committee (中共中央党史和文献 硏究室), excerpts from xi Jinping's treatise on poverty alleviation (习近平扶贫论述摘编), [M]. Central Literature Publishing House (中央文献出版㘹), 2018.

Wang Furong (王芙蓉), “Qinghai Province Invested 11.4 Billion Yuan To Ensure Poverty Alleviation in 2018” (2018年青海省投入 114 亿元全力保障脱贫攻坚), [N]. Qinghai Daily (青海日报), 2019.

Wang Jin (王进), “Xi Jinping Attended And Delivered An Important Speech at the Conference on Poverty Alleviation and Development of CPC Central Committee” (习近平出席中央扶贫开发 工作会议并作重要讲话), Cnr.cn (央广网), 2015.

Wang Xiaoqing, Yang Hongxia (汪晓青, 杨红霞), “Qinghai Successfully Achieved Its Goal Of Poverty Alleviation In 2018 And will make every effort to reduce deep poverty” (2018年脱贫目标 顺利实现青海将全力攻坚深度贫困), Xinhuanet (新华网), 2019.

Wang Xingrui (王兴瑞), “Decisive Progress Has Been Made In Poverty Alleviation In Xinjiang” (新 疆脱贫攻坚取得决定性进展), [N]. Xinjiang Daily (新疆日报), 2020 (4).

Wang Yanzhong (Ed.) (王延中主编), 2020. Annual report on the development of ethnic in China (2020) (中国民族发展报告)2020年)), [M]. Social Sciences Academic Press (社会科学文献出 版社).

Whitfield L., 2008. "Pro-poor growth: A review of contemporary debates. Copenhagen: Danish Institute of International Studies", Elites, Production and Poverty Research Program (DIIS).

World Bank. 2000. World development report (2000/2001): Attacking poverty. New York: Oxford University Press.

World Bank Group (世界银行集团), “The World Bank Annual Report 2018: Ending poverty, Investing in Opportunity” (世界银行2018年度报告:终结贫困 投资于机会), Worldbank.org (世界银 行网站), 2019.

Xian Hui (咸辉), "Report on the Work of the Ningxia Hui Autonomous Region Government 2019" (2019年宁夏回族自治区政府工作报告), [J]. Bulletin of the Standing Committee of the People's Congress of Ningxia Hui Autonomous Region (宁夏回族自治区人民代表大会常务委员 会公报), 2019 (4).

Yang Jing. 2017. Welfare, work, and poverty: Social assistance in China. Oxford University Press.

Yang Yalin (杨亚林), “Transform Advantage In Party Building Into Advantage In Poverty Alleviation” (把党建优势转化为扶贫优势), [N]. China Organization and Personnel News (中国组织 人事报), 2018 (4).

Zhang Chi, Yu Qiongyuan. (张弛 郁琼源), “The Central Government Allocated Over 106 Billion Yuan For Poverty Alleviation In 2018” (中央拨付2018年财政专项扶贫资金1060多亿元), Xinhuanet (新华网), 2018. 
Zhang Haomiao. 2017. The minimum living standard guarantee system and citizenship cultivation among the poor in China. Asian Journal of Social Science 45: 483-506.

Zhang Qi, Wan Jun, Shi Zhixiang, Kong Mei, Shen Yangyang (张琦, 万君, 史志向, 孔梅, 沈扬扬), “Fight Together Against Poverty” (凝心聚力打好脱贫攻坚战), [N]. China Economic Times (中 国经济时报), 2019 (3).

Zhao Renwei, Li Shi, Carl Riskin (赵人伟, 李实, 卡尔.李思勤), China's Retreat From Equality: Income Distribution and Economic Transition (中国居民收入分配再㸴究), [M]. China Financial \& Economic Publishing House (中国财政经济出版社), 1999.

Zheng Zhilong, Ding Huixia, Han Heng, Sun Yuantai (郑志龙, 丁辉侠, 韩恒, 孙远太), research on performance evaluation of government poverty alleviation and development (政府扶贫开发绩效 评估硎究), China social sciences press (中国社会科学出版社), 2012.

\section{Comments}

Publisher's Note Springer Nature remains neutral with regard to jurisdictional claims in published maps and institutional affiliations. 